Provided for non-commercial research and education use. Not for reproduction, distribution or commercial use.

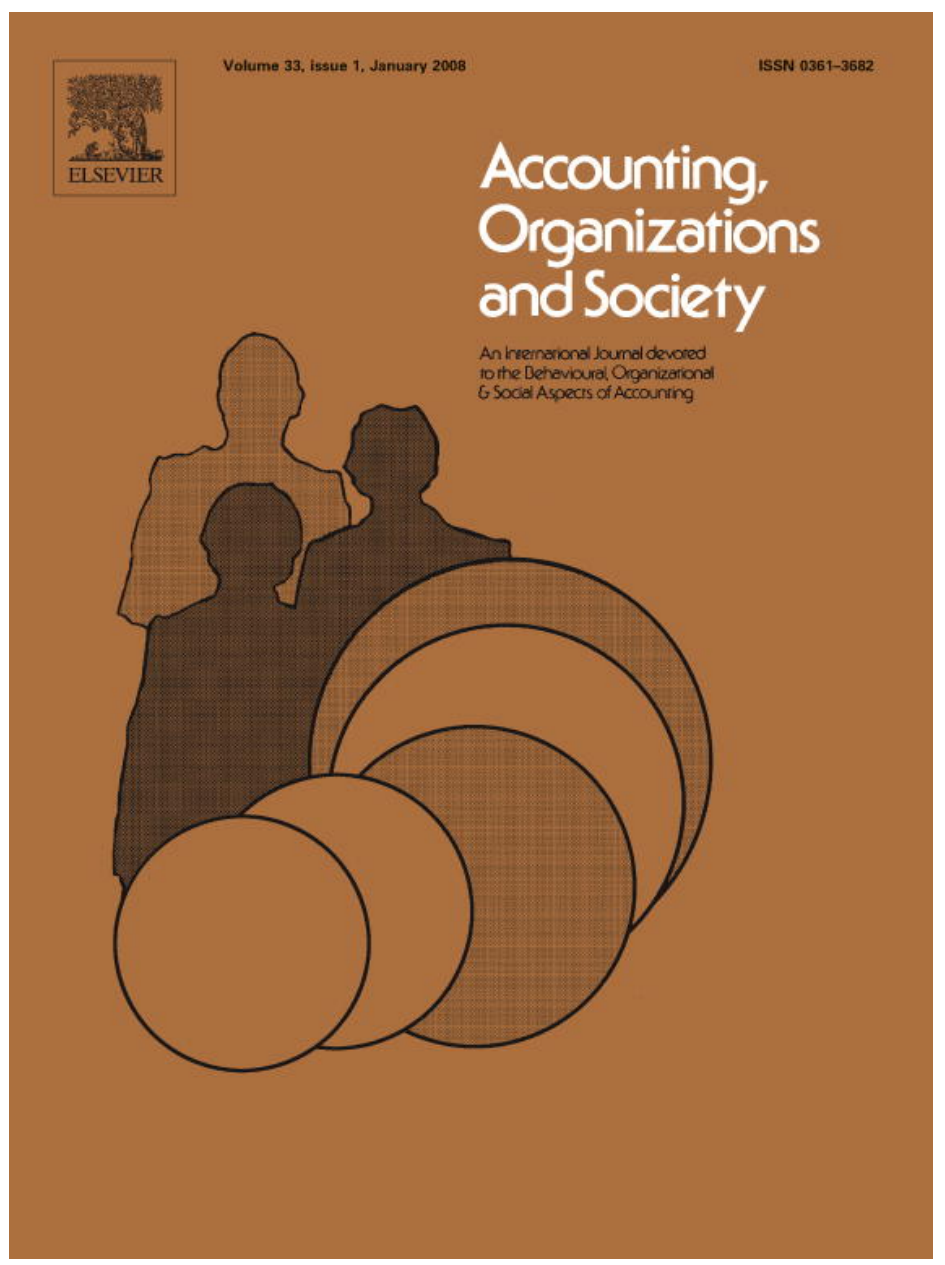

This article was published in an Elsevier journal. The attached copy

is furnished to the author for non-commercial research and education use, including for instruction at the author's institution, sharing with colleagues and providing to institution administration.

Other uses, including reproduction and distribution, or selling or licensing copies, or posting to personal, institutional or third party websites are prohibited.

In most cases authors are permitted to post their version of the article (e.g. in Word or Tex form) to their personal website or institutional repository. Authors requiring further information regarding Elsevier's archiving and manuscript policies are encouraged to visit: 


\title{
Accounting and gender across times and places: An excursion into fiction is
}

\author{
Barbara Czarniawska *
}

GRI, School of Business, Economics and Law, Göteborg University, Box 600, SE 40530 Goteborg, Sweden

\begin{abstract}
The focus of this paper is on changing perceptions of accounting in different times and in different cultural contexts, with the special emphasis on the issues of gender. The material used is a combination of fiction and research results, and the scope of analysis extends from the end of the 18th century in Central Europe through the birth of capitalism in Poland to the contemporary global economy, as portrayed in the novels of Douglas Adams.
\end{abstract}

(C) 2006 Elsevier Ltd. All rights reserved.

\section{Fiction as field material?}

Fictional works may tell truth about economic realities; while apparently factual works on economic realities may be infiltrated by fiction, so that they can offer covert myths and fantasies, or disguised dramas with heroes and villains (Watts, 1990: 3).

\footnotetext{
A plenary presentation at the 8 th Interdisciplinary Perspectives on Accounting Conference, Cardiff, 10-12 July 2006. I would like to thank Mahmoud Ezzamel for encouraging me to write this paper, and Anthony Hopwood for his helpful comments.

* Tel.: +46 31773 1552; fax: +46 317735619 .

E-mail address: barbara.czarniawska@gri.gu.se
}

In this paper I show how accountants were perceived through times in selected cultural contexts, using fiction, among other sources, as my field material. The justification for such a move is complex and variegated. To begin with, fiction - such as novels - can be seen as complementing both fieldwork and conventional organization theory:

Fiction accomplishes the feat which organization theory often misses: it combines the subjective with the objective, the fate of the individuals with that of institutions, the micro events with the macro systems.

Novels also transmit tacit knowledge: they describe knowledge without analysing it, thus tapping on more than an explicit message characteristic for paradigmatic teaching 
(Guillet de Monthoux \& Czarniawska-Joerges, 1994: 9).

Apart from this difference in genres that can be exploited for reaching new insights, the realistic novel can provide field material quite literally. Bukowski's description of his work as a post-office clerk (Rhodes \& Brown, 2005) offered an idiosyncratic, but no doubt authentic experience of such an occupation. Such field material is especially valuable in at least two circumstances: as a historical source not accessible to conventional research and as a source of illustrations concerning sensitive issues that are difficult to observe or to extract from interviews.

But even when not offering a realistic depiction of actual practices, the novel, and especially the popular novel, has much to offer a researcher interested in economic and organizational practices. In the first place, it offers an image of an occupation that is common at a certain time and in a certain place: the risk-filled, masculine work of finance in contemporary western economies, for example (Czarniawska, 2004). In the second place, as suggested by the circuit model of culture (Johnson, 1986-1987), the novel propagates this kind of image, influencing actual practices and career choices (Czarniawska \& Rhodes, 2006).

One of the issues that might especially gain from such "excursions into fiction" is the gendered character of economic activities. Fiction can be the most promising source of field material for studying discriminatory practices, or what I called coercive gendering, in organizations (Czarniawska, 2006) because a prolonged, direct observation of a workplace is often difficult to conduct. Discrimination, on the other hand, might be a periodic or temporary phenomenon rather than a routinized practice and might not be revealed to the researcher, or it might be spatially limited to areas that remain outside the observer's sight. Furthermore, an interpretation of real life situations as coercive gendering can easily be contested. So although participative or direct observations, difficult as they are, will remain the primary ways of collecting field material, fiction - literature and film - can be also usefully exploited. Here, as announced in the motto for this paper, I intend to blend them in my analysis of different gendering of accounting profession in different cultural contexts. ${ }^{1}$

Neither cultural perspective, nor excursions into fiction are topics unknown to accounting research. Anthony Hopwood (1994:300) has long encouraged accounting scholars to acknowledge the importance of the cultural context of both accounting and accountants. Victoria Beard (1994), for instance, has traced the images of accountants in the movies. Having analyzed 16 US and British movies released since 1957 in which accountants have been portrayed, she noticed that "[a]ccountants are not traditionally regarded, at least by Hollywood, as part of the top management team. They are seen, instead, as undifferentiated cogs in the wheel of economic progress, cogs to be replaced without a moment's hesitation by other faceless accountants or, preferably, by advanced technology" (Beard, 1994: 305). The latest version of Mel Brook's The Producers (2005) clearly illustrates this observation, in its image of bookeepers working in rhythm.

Two of the films' accountants analyzed by Beard were women: Loretta Castorini in Moonstruck and Mollie (and her mother, actually) in Look Who's Talking. Beard, without commenting on their gender, included them into a category of "transformational" accountants, i.e. protagonists whose character develops surprisingly during the movie. I would add that the transformation in both cases consists of the triumph of "feminine" traits ("impulsive, full of sentiment, and hasty in judgment", says Lehman, 1994 quoting the historical arguments against admitting women to accounting) over the stereotypical accountant's traits (Bougen, 1994; DeCoster \& Rhode, 1971). This contrast is especially visible in Look Who's Talking, where Mollie's blind date is a CPA.

Neither is gender focus alien to accounting studies. Volume 17 of Accounting, Organizations and Society (1992), dedicated half of Issue 3/4 to "Feminist Perspectives on Accounting Research". These articles, which were of great help in my anal-

\footnotetext{
1 The concept of "cultural context" is further explained in Czarniawska-Joerges (1991).
} 
ysis, focused on the history of accounting in UK and USA. Hantrais (1995) extended the comparison to France, concluding that although equality measures within the profession were helping women in UK, the generally better situation of working women favored French professionals. Nevertheless, in both countries women remain a minority in professional accounting practices.

In this paper, following the example of Evans, (forthcoming) and Maltby, 1997, I chose as my starting point Central Europe in the 19th century. This choice is justified in two ways: because, at least according to Chandler (1962, 1977), the model of modern business management was imported to the United States from Germany; and because Poland represents a typical case of a country that was first far removed from this model and then tried to emulate it with varying success. More importantly, Poland is a country where accounting has been and remains a "feminine occupation". I end with descriptions of accounting in the novels of Douglas Adams, again for two reasons: because of the brilliance of his observations, and because his descriptions represent a "global" variation of business management - a US model filtered through a local (UK) tradition.

Gender and class are among the most visible aspects that distinguish the different traditions of business management in different cultures; this paper focuses mostly on gender, while nevertheless adopting an intersectional perspective (Crenshaw, 1989) whenever possible.

\section{Europe at the end of the 19th century}

To be concerned with money matters, to balance expenses and income, was considered vulgar and left to the care of stewards. (...) This supreme contempt of an ordered economy is also characteristic of all speculators; it was the common ground on which haute finance and the old aristocracy met (Sombart, 1922/1967: 87).

Between haute finance and the old aristocracy lay the middle class: the burghers. Josephine Maltby (1997) quotes a scene from Gustav Freytag's bestselling novel Soll und Haben (Debt and Credit) from 1855, in which Sabine Schroeter presents her fiancé, Anton, with the private ledger of the company owned first by her father and now by her and her brother, because Anton is to be the new business partner in the company. Anton protests feebly and humbly, whereupon the brother says "No, brother, Sabine has acted like an astute merchant" (Maltby, 1997: 69). Earlier on, showing the ledgers to Anton, Sabina said: "Come, then and see my debit and credit".

The novel has been acclaimed for its veracity; and the author was actually a journalist. Was his depiction accurate? As Maltby points out, the novel sings the praise of the middle class at the expense of Jews and the aristocracy as the bearers of old fortunes and the only group previously allowed by their religion to deal with money. The Protestant bourgeoisie gave itself this right and aspired to the higher virtues of temperance and prudence (McCloskey, 2006). Accounting, pointed out Maltby, was the technology to prove those virtues.

Maltby has highlighted a compelling point concerning realism - of the novel and of accounting. When Freytag's contemporary readers praised the novel for its realism, they were not referring to the Stendhalian "novel as a mirror riding along a highway" (Czarniawska, 1999). They saw it as realistic "because it showed them as they wished and intended to be: diligent, rational, reliable, and therefore uniquely fitted to take command politically as well as economically" (Maltby, 1997: 83). Similarly, the realism of accounting is a more complex matter than merely reflecting the reality. Why, asks Maltby, are the readers of accounts prepared to believe in veracity of accounting? And she answers: "The persuasiveness of accounting derives (...) from its place in a preexisting moral calculus of obligations and entitlements" (p. 85).

There are two other aspects contained in Soll und Haben, which have greater fascination for me than they had to Maltby. The first is a relationship between women and accounts; the other is a relationship between Germany and Poland. Anton falls first in love with a daughter of an aristocratic family with property in Poland (the country was at that time parceled out between Germany, Austria, 
and Russia). Anton attempts to teach Lenore to keep household accounts, "but she is too scatterbrained to add them up" (Maltby, 1997: 75). She is too scatter-brained not because she is a woman, but because she belongs to an aristocratic family, and the whole family is poorly educated and incompetent in handling their money. In contrast, the middle-class Sabine knows her debits and her credits, and thinks like an astute merchant. Middle-class women were used to handling money.

In two episodes set in Poland, Anton and his future brother-in-law are shown as creating order from chaos. This interpretation is partly racist, partly historically correct: there was no middle class in Poland, and the German middle class saw it as their historical mission to civilize the Poles by introducing bourgeois virtues. The nobles either fought in national uprisings or squandered their property by gambling; the peasants abhorred long-term investments and modern methods of administration. The commandments of Catholicism reserved business possibilities to the followers of Protestantism and Judaism. Patriotism was equated with lack of business sense.

\section{Is Polish business enterprise an oxymoron?}

I can't remember

where, when, and why

I let someone open

this account in my name.

We call the protest against this

the soul.

And it's the only item

not included on the list.

Wiesława Szymborska, from Nothing's a gift, 1993.

Although it can be claimed that no proper middle class emerged in Poland until after 1989, accounting was adopted earlier, when it became a profession, and therefore a proper occupation for the positively thinking intelligentsia. Wikipedia defines intelligentsia (from the Latin, intelligentia) as "a social class of intellectuals and social groups close to them (e.g. artists, school teachers), which can be also seen as a class of mental workers in opposition to non-working aristocracy or business owners on the one hand and to manual laborers on the other". ${ }^{2}$ Its emergence is usually explained by the decline of the feudal system in Russia, and by legal prejudice against the nobles in partitioned Poland, leading to their impoverishment. Additionally, the Polish estate economy of the 16th and 17 th centuries was supported by an anti-capitalist institutional order that limited the conditions for entering the market, attempted to control prices, supported autarchy, and spread negative attitudes toward investments (Beksiak, 1994; Czarniawska, 2002).

"In both countries members of the 'déclassé' fraction of the landed nobility, seeking to maintain in an urban environment their traditional style of life, had to separate themselves from the 'bourgeois' middle class" (Gella, 1976: 13). The central point of the ethos of the intelligentsia was the value of education and knowledge as opposed to the right of birth (aristocracy) and money (bourgeoisie).

The intelligentsia was born from an encounter between opposite ideals: the positivist and the romantic. The clash between the two has been described in a novel by Bolesław Prus, The Doll (Lalka, 1890/1972), one of the classics of Polish literature. Its main hero, Wokulski, came from a poor (although probably noble) family. He was earning his life as a waiter and spending his free time studying: first in the Preparatory School (a kind of a college) and then in the Main School (at present, Warsaw School of Economics; the only higher education establishment permitted by the Russian occupants at the time of the action of this novel). He engaged in the political upheavals of his time, spent some time in exile, but continued his education. Back in Poland, he married the widow of his former principal, a polonized German, and then doubled her property. After her death, he continued to invest with spectacular success, and turned the old shop into an elegant store in the center of Warsaw. After some hesitation, he was admitted as a self-made man into the salons of Warsaw, where his coming union with the

\footnotetext{
${ }^{2}$ http://en.wikipedia.org/wiki/Intelligentsia, 25 September 2005.
} 
daughter of an impoverished aristocrat was accepted. Alas, Wokulski soon discovered the indifference and the flirtatious nature of his beloved. He withdrew from his business and committed suicide, simultaneously exploding a stone bearing an inscription that documented the romantic love of several generations.

The standard interpretation of this national classic is (for reviews see Czarniawska-Joerges, 1994a; Holmgren, 1998) that Wokulski was infected by Positivist ideals (mostly as expressed by Herbert Spencer), and tried to realize them, introducing the notions of modern business into Poland. He met many traditional hindrances in his endeavor; but his undoing was his own Romanticism, which lured him into a romantic love.

One of the other characters of the novel is Wokulski's accountant, Ignacy Rzecki. Rzecki was, like Wokulski, an employee of the old owner, Mincel, and decided to remain with the new owner. Both attracted and frightened by the latter's modern ideas, Rzecki remembered well the old times when the supplies and the accounts were under the control of the German owner. Mincel trained the salespeople, and gave them lessons in accounting, economic geography, merchandise, and business ethics: not to save was considered a crime equivalent to theft. In time, shopkeepers became business people; a development that Rzecki did not quite approve of:

In my times the principal was a father and a teacher to his employees and the most attentive servant of his shop; his mother or wife were the housekeepers, and all family members its employees. Nowadays the principal takes the income, usually does not know much about commerce, and his main worry is that his children do not become merchants... (translation from CzarniawskaJoerges, 1994a: 53).

Indeed, the first condition made by his aristocratic fiancée was that Wokulski had to sell the shop; it was shameful even to own it. Yet it was certainly not a petty commerce, but truly "The Ladies' Paradise" - as Zola called the novel that described the first large store, Bon Marché in Paris.
Wokulski procured the finances and secured the supplies, organized the administrative side, employed salesmen, and, much to Rzecki's sorrow, left the shop alone. Rzecki was responsible for the accounts and for the window decoration (observe how accounting and marketing went hand in hand even then). The windows, which were redecorated every week, were supposed to reflect the riches of the shop and attract attention with their fashionable products and ingenious tricks. Organization was becoming complex, and personnel problems grew beyond the paternalistic solutions of the old owner. Division of labor, personnel management, incentive systems - all were problems that did not yet have names, but were noticed even by the old-fashioned Rzecki. The shop had branches (bankrupt shops that Wokulski bought out, leaving owners as managers or accountants) and it set the standard for new shops to follow. A new era in retail commerce was beginning, although the distance between Wokulski's shop and the department store described by Zola (50 departments and 3045 employees) was still large.

Even Rzecki, the dry and down-to-earth accountant, had a romantic dream. In his case, it was a dream of the return of Napoleon, under whom he has fought as a young man. Fortunately for his accounting career, however, no Napoleon was in sight.

In light of my present concerns, I would like to offer a "novel reading" (De Vault, 1990) of this Polish classic. In the first place, as can be visible even in my short synopsis, both men have positivist and romantic characteristics. Indeed, as pointed out by Brown (1989), the rhetorics of Positivism and Romanticism are inseparable; together they form the double rhetoric of modernity (Czarniawska, 1999). It can be claimed that Wokulski's attempt to introduce modern capitalism to Poland was in fact a romantic endeavor: he died a romantic hero, of love, but for an impossible cause.

I would also suggest that Wokulski and Rzecki ought to be seen as a pair, although in no sexual sense. They do reflect a traditional division of roles in a family business. Wokulski is the man: he travels, makes risky decisions, invests, speculates, provides money, and spends it. Rzecki is the woman: he stays at home, saves, tries to limit the risks, and 
keeps the accounts. This is congruent with the traditional image of accounting in Poland as a feminine occupation, but also with the role of women managers in the global economy (Calás \& Smircich, 1993).

The tetralogy of Maria Dabrowska, Nights and Days (Noce i Dnie, 1931-1934), which took place between 1863 and 1914, continued the epos of the transformation of a feudal country into a capitalist one and the accompanying transformation of the nobility into the intelligentsia. By that time, many men had vanished in various uprisings against the Russian occupants, and others were punished for their patriotic outbursts by the confiscation of their estates. Women, especially unmarried women, needed to work to help their impoverished families. As Dabrowska says of one such young women: "She was fully convinced that a woman should work; besides, everybody in her environment shared this conviction" (vol. 3, p. 36, transl. BC).

Young women were usually educated, often better educated than men, who were busy participating in various military endeavors. Nights and Days is filled with many such women, and the hierarchy of occupations seems clear. The most obvious one was that of a teacher; but for many reasons, it was not for everyone. Public and private schools opened, and the need and the resources for private tutoring diminished; the market became satiated. Many of the young women discovered that they had neither pedagogical talents nor pedagogical inclinations. Dressmaking was apparently acceptable; photography and book binding were also "occupations for women". But the best way to earn a living, it seems, was by learning "buchalteria" (book keeping; the German word in Polish suggests origin of this skill). One occupation still considered beyond the dignity of the nobles was trade - "standing in the shop", which, in The Doll, Izabella saw as degrading for noble men and women alike. However, by the end of the century, noblewomen started engaging in even this occupation. The next generation, the children of Barbara and Bogumił, the protagonists of Nights and Days, will in increasing numbers attend French and then Polish universities, men and women alike.

\section{The capitalist Poland and the Chief Accountess}

Stereotypes (...) are always insecure, both because they are inadequate to experience in the world and because they are internally contradictory (Alan Sinfield as quoted in Watts, 1990: 199).

The stereotype of a bookkeeper as a dry, boring, middle-aged man (Rzecki indeed), but also "cold, aloof, and impersonal" (DeCoster \& Rhode, 1971) is practically "global", and is known also in Poland; but there it shares place on the shelf of the stereotypes together with another, which I called the Chief Accountess (Główna Księgowa). Although it dates to the so-called first beginning of Polish capitalism (1919-1939), its roots are older, as I suggested before.

My mother, who could well have been a child of Bogumił and Barbara (she was born in 1907), dreamed of becoming a certified accountant. Accounting, however, was not taught at Batory University in Vilnius where she lived, and her mother, by then a widow, would not allow her to go to study at Warsaw School of Economics. After the World War II and the re-patriation of Poles from Lithuania, my mother worked as an accountant in Białystok, Poland. Her high school certificate was enough.

What historical contingencies contributed to the emergence of the stereotype of accounting as a woman's job? Many. Married women in medieval Poland maintained control of immovable property that came in their dowries; a law, changed in the 16th century, allowed men to administer their wives' dowries, together with any property they might have acquired during the marriage. However, husbands could not sell their wives' property without their permission, and women had the right to revoke their husbands' power if they could prove that their estates were poorly managed (Marrese, 2002). But after the Eastern Poland became annexed by Russia in 1772, a Russian law from 1715 affirming women's right to purchase, mortgage, and sell property encompassed Polish women. But because they still needed their husband's permission, the most active women in the property markets were widows (Marrese, 2002). 
Even Swedish law (the code of 1734) recognized separate property in marriage, although it was not until the 1870s that Swedish women acquired full control over their property. Nevertheless, accounting is not a female profession in Sweden. In Victorian England, wives kept business accounts for their husbands who farmed or worked in retail; this did not prevent accounting from being seen as an exclusively male occupation in Britain, however (Walker, 2002: 384-385). In fact, the closest comparison to the Polish women would be the wives of Viking chiefs, who ruled the villages when their husbands went off trading and on military expeditions (Magnusdøttir, 1999), for Polish noblewomen administered their land while their men were away for incessant independence wars and uprisings.

In that they might have been similar to the Finnish women who ran factories, public offices and families during the World War II. After the war, however, "the old boys" came back from the front with a ready network of power and simply took over (Czarniawska-Joerges, 1994b). Although Polish men also came back from the war, the socialist regime did not send women back home. The British government tried to keep women at work, but because there were few child-care facilities and because it was possible for families to survive on a single income, many married women stayed at home (Thane, 1994). Polish families needed an extra income, and Polish women had both state daycare and their mothers' help, allowing them to keep their jobs - and among those was accounting (Bystydzienski, 1989; speaks of "credit and insurance", but it is hard to know what she means, as neither credit nor insurance really existed in the socialist economy). Magdalena Sokołowska, who conducted a study of Polish women in the decision-making elites of the 1970s, noticed that they often held extremely high professional positions; but rarely, if ever, positions of formal power (Sokołowska, 1981).

During my field study of the management of the City of Warsaw in 1994, I participated in a meeting between the representatives of the City Treasury and their contractors - a transportation enterprise. They negotiated prices and dates of delivery. The company, which had a legal form of a budgetary plant, was represented by the Deputy General Manager (a male engineer) and a female accountant:

DGM: Madam A here is an expert in this kind of things. We are an enterprise without problems, do you know that? Although this brings only control down on us because everybody suspects something, but they can't find a thing that doesn't work.

A: It's not as simple as that. You can't imagine the mental gymnastics I have to go through to fill out [financial reporting forms for the budgetary plants]. We all know that it is nonsense, that we aren't a budgetary plant but a normal company.

CT: We keep you in this form because we have been trying to escape this special tax on salaries [paid only by companies].

DGM: We will fix that, even if it is $\mathrm{X}$ who is our Chief Accountant. But Madam A does his dirty work.

A: As women always do (Czarniawska, 2000: 127-128).

It needs to be added that the City Treasurer was a woman, too. After a reform of city management, a new position - the Director of Finance - was created. It went to one of her male colleagues, although she applied and was convinced that the job would be hers.

When I studied the management of the City of Stockholm in 1996, the City Treasurer was a man with long and wide experience of the job. After the reform of city management, a new position of the Director of Finance was created. It went to a younger man with little experience, and that in a private company; the Treasurer became his subordinate and left shortly afterwards (Czarniawska, 1999). "Accounting and finance" might be sometimes taught in the same university departments, but they certainly have a long separate history in business practice. Also, these vignettes corroborate my "novel reading" of The Doll and the social character of gender: it is not always equivalent with biological sex. Accounting and treasury jobs are "feminine", whereas finances are "masculine". 
It needs also to be pointed out that there is no difference between "bookkeepers" and "accountants" in the Polish language. Although there are two nouns to describe the activity (ksiegowość and rachunkowość), they are used synonymously, and the only professional descriptions are "bookkeeper" (ksiegowy, ksiegowa) and "auditor" (rewi$z o r$ ), both dominated by women. This is why the division of the occupation into professional accountants and bookkeepers, which explains the development in England and Wales (Kirkham \& Loft, 1993) does not apply to the Polish case. However, a similar difference might be produced by the organizational hierarchy ("assistant accountant" vs. "chief accountant").

Although the global order (that is, various local imitations of US companies) has entered Poland widely and quickly, the stereotype, nay, the archetype of the Chief Accountess remains. In 2004, the main Polish daily, Gazeta Wyborcza, ran a discussion forum on matters related to work, under the label "Dilbertose". "The Mean Chief Accountess" was one of the main figures evoked. The voices were divided. Most were hostile: the Chief Accountess (nobody considered the possibility that it could be a man) was mean, hated, hostile towards the "real workers", servile toward the top bosses, and arrogant. One voice claimed that this was an exaggerated picture and quoted her own experience of being helped in her career by a Chief Accountess.

Three voices were of Chief Accountesses themselves. Two of them said that people did not understand what a difficult position accounting is, and how risky in its legal responsibility. One of them said that retirement was a real relief. The third agreed with the stereotype, but excepted herself from it, saying that she was always on the side of the employees and not the managers, as "human capital is the most important capital in each company".

One voice was that of a male auditor:

In my work I meet many different Chief Accountesses, but one thing is certain: they deserve an enormous respect. Accountants live in the world of taxation and accountability abstraction which is incomprehensible to the operational workers. (...)
Accountants need to continue their education life long. Rules change continuously and quickly, the bosses save money on manuals and training, and the accountants need to confront tax authorities - remorseless and often absurd. Top bosses are truly the guilty ones - those who demand exotic solutions of their problems, for which the accountants will be punished, not they.

The accountants' meanness might be a result of stress and inferiority complex many older bookkeepers do not have a university degree. I know what a monotone and trying job it is and I would never want to be a Mr. Chief Accountant. The Finance Director, that's something else! (Hektor, 24.03.04).

Globalization will most likely mean more men in the new position of Finance Director, and women doing the "monotone and trying" jobs. Indeed, in a recent novel, Love in the Sanatorium (Józefowski, 2004), one of the protagonist is a Chief Accountess of whose work the reader learns only that it was "monotone" (this is repeated several times).

The World Bank Report offered some statistics that might be relevant. The Polish Classification of Economic Activities has a category called "financial services", which covers everything from banking through public accounting to stock market analysis and brokerage. In 1994, men constituted $22.9 \%$ and women $77.1 \%$ of this category (Balcerzak-Paradowska, 2004: 22). In 2002, these figures had changed to $31.5 \%$ men and $68.5 \%$ women (Parlińska \& Sawicka, 2004: 112), a steady trend through these eight years. A study of entrepreneurship showed that women constituted $37 \%$ of entrepreneurs in 2001. The most frequent university degree among woman entrepreneurs was economics $(22 \%$ compared to $4 \%$ among men entrepreneurs), and companies within the category of "financial services" (most likely public accounting) were twice as likely to be owned by women than by men (Lisowska, 2004).

The Accountants Association in Poland is the oldest (since 1907) and the largest Polish organization for professionals within accountancy and 
finance (http://www.skwp.org.pl). The president, two vice-presidents, the secretary general and the treasurer are all men. In 1989, the Main Board of AAP decided to create a National Board of Chartered Accountants (NBCA). The AAP's Research Council has 33 members, of whom 16 are women, 11 of them chaired professors. The Chair of the Council and his two Vice-Chairs are men; the Council's Secretary is a woman. In other words, the same pattern as everywhere: a visible domination of women in accounting, but the positions of power and prestige go to men.

What can be expected in future? Science-fiction is a genre that specializes in answers to such questions.

\section{Douglas Adams and the global economy}

Much of the world that we move in has been seen through Douglas's eyes and become clearer. Which is to say the very confusion and absurd lack of clarity of our world has become clearer.

Stephen Fry, in the Foreword to The Salmon of the Doubt

I chose books of Douglas Adams to illustrate accounting in the global economy for two reasons. One is that Adams was uncannily astute in observing the pivotal role of accounting and marketing in contemporary organizations at a time when everyone else was concentrating on leadership and such matters. Furthermore, although the context of Adams intergalactic corporations is undoubtedly English, the UK organizations are a very interesting case of globalization (that is, a translation of US models throughout the world), being only once removed from the original.

Like William Gibson and Neal Stephenson, the two cyber prophets, Adams sees the global economy as being composed of gigantic corporations and minuscule enterprises, with nothing in between. Thus the examples of accounting-like activities come either from the two-person (at the most) detective agency of Dirk Gently, or the intergalactic publishing corporation, The Hitchhikers Guide to the Galaxy.

\section{Dirk Gently, an entrepreneur}

Two of Gently's activities are relevant in the present context: billing and reading accounts. Here is the best example of billing:

"Ah, Mrs Sauskind", he said in an answer to the caller, "my oldest and may I say the most valued client. Good day to you, Mrs. Sauskind, good day. Sadly, no sign as yet of young Roderick, I'm afraid, but the search is intensifying as it moves into what I am confident are its closing stages, and I am sanguine that within mere days from today's date we will have the young rascal permanently restored to your arms and mewing prettily, ah yes the bill, I was wondering whether you received it". (...) (Dirk Gently's Holistic Detective Agency, 1987/ 1996: 116)

Roderick is a cat whose disappearance caused Mrs. Sauskind to seek Gently's services (he specialized in finding cats, including the Schrödinger's).

"Yes, expenses were, well, expensive in the Bahamas, Mrs. Sauskind, it is in the nature of expenses to be so. Hence the name". (...) "Of course I will explain to you again why the trip to the Bahamas was so vitally necessary", said Dirk Gently soothingly. "Nothing could give me greater pleasure". (...) (118)

It is the specificity of English language that makes expenses expensive, but in other languages there are similar hints: in Polish, as in English, for example, the costs are costly.

"You sadden me, Mrs. Sauskind. I wish I could find it in my heart to tell you that I find your scepticism rewarding and invigorating, but with the best of the world I cannot. I am drained by it, Mrs. Sauskind, drained. I think you will find an item in the bill to that effect. Let me see". (...)

"Detecting and triangulating the vectors of interconnectedness of all things, one hundred and fifty pounds'. We've dealt with that. 
"Tracing the same to beach on Bahamas, fare and accomodation". A mere fifteen hundred. The accommodation was, of course, distressingly modest.

Ah yes, here we are, "Struggling on in the face of draining scepticism from client, drinks - three hundred and twenty-seven pounds fifty".

Would that I did not have to make such charges, my dear Mrs. Sauskind, would that occasion did not continually arise. Not believing in my methods only makes my job more difficult, Mrs. Sauskind, and hence, regrettably, more expensive". (...)

"I do appreciate, Mrs. Sauskind", continued Dirk, "that the cost of the investigation has strayed somewhat from the original estimate, but I am sure that you will in your turn appreciate that a job which takes seven years to do must clearly be more difficult than one that can be pulled off in an afternoon and must therefore be charged at a higher rate. I have continually to revise my estimate of how difficult the task is in the light of how difficult it has so far proved to be".

"My dear Mrs. Sauskind - or may I call you Joyce? Very well then. My dear Mrs Sauskind (...) do not worry yourself about this bill, do not let it alarm or discomfit you. Do not, I beg you, let it become a source of anxiety to you. Just grit your teeth and pay it" (Dirk Gently's Holistic Detective Agency, 1987/1996: 119-120).

A reader sharing a common prejudice against accountants might formulate an observation similar to one offered by Richard MacDuff, Dirk's chum from university times:

"I have to say that it sounded a bit like an excuse for exploiting gullible old ladies".

"Exploiting"? asked Dirk. "Well, I suppose it would be if anybody ever paid me, but I do assure you, dear Richard, that there never seem to be the remotest danger of that. (...) Meanwhile I give a lot of charming and silly old ladies something to be happily cross about and virtually guarantee the freedom of their cats" (Dirk Gently's Holistic Detective Agency, 1987/1996: 120).

At another occasion, Gently's billing philosophy is formulated even more explicitly:

On his own bills when he issued them (...) he usually went to a little trouble about the items charged. He constructed essays, little paragraphs to describe them. He liked the client to feel that he or she was getting his or her money worth in this respect at least (The Long Dark Tea-time of the Soul, 1988: 212).

But it is not merely that Gently takes good care of the bills. As an entrepreneur and a detective, he actually delivers - not the required services, and not to the specific client, but he does deliver! He delivers services that profit the whole of humanity, which perhaps could serve as a role model - for universities, for instance, in their new role of service providers?

Gently's behavior here is in straight opposition to a stereotypical image of an accountant in the Anglo-American context: "coldness, aloofness, nonsociability, submissiveness, shallowness, passiveness, weakness and without sensitivity" (DeCoster \& Rhode, 1971, p. 654). The traits least likely to characterize an accountant, according to the DeCoster and Rhode study, are an exact description of Dirk Gently: "lazy, witty, rebellious, low-brow, fun-loving, athletic and talkative" (p. 653). One almost wonders if Adams had read the article - or watched John Cleese enacting the stereotype (Bougen, 1994). It is also interesting to notice that neither the stereotype nor the counter-stereotype include traits commonly considered "feminine"; thus the "true women" in the Hollywood movies can easily leave the professional framing by reverting to their gendered natures, as it were.

Another activity of Gently's is that of reading accounts. As a detective, Gently is used to reading other people's accounts, and as we shall soon see, he does it quite expertly. As we see in The Salmon of Doubt, his own accounts fill him with horror:

Dirk tipped his unopened bank statements on to the kitchen table, and stared at them with loathing. (...) Viewed in a certain light, 
the entire structure of his adult life could be seen as means of avoiding opening his bank statements.

Someone else's bank statements - now that was a different matter. He was rarely happier than when poring over somebody else's bank statements; he always found them rich in colour and narrative drive (...)

He could not possibly, possibly be over $£ 22,000$ overdrawn. (...) There must be some mistake. Some terrible mistake. The chances were, of course, that he had made it, and as he stared, trembling, at the paper he realised, quite suddenly, that he had.

He had been looking for a negative number and had therefore assumed that was what he was looking at. In fact the account stood at $£ 22,347.43$. In credit.

Credit. ... He'd never known such a thing. Didn't even know what it looked like. Hadn't recognised it. (...) (The Salmon of Doubt, 2002: 217-218)

If the readers think that this situation is unlikely to happen in a real organization, they are sadly mistaken; many a time, I have witnessed the horror produced by a positive balance in the accounts of Swedish municipalities (Czarniawska, 1997; 2002). Debt is a usual occurrence and can be dealt with in routine ways; credit is a serious problem in non-profit organizations. As in Gently's case, unusual situations produce a surge of creativity:

Irregularly large sums regularly paid in. (...) What were they? Interest payments that had been accidentally credited to the wrong account? If they were interest payments, that would account for the fluctuations in the amounts. But it still didn't make for the simple reason that over $£ 3000$ interest a week represented the interest on two or three million pounds and was not the sort of thing that the owner of such an amount of money was going to allow to be misplaced, let alone for seven weeks in a row. (...)

On reapplying his attention to the papers, he realised something else that would have occurred to him straightaway if he hadn't been so flustered. There was, of course, a code next to each entry. The purpose of the code was to tell him what kind of entry it was. Easy. Each payment had reached his account by international transfer. (...) That would also account for the fluctuations. International exchange rates. If the same amount of a foreign currency was being transferred each week, then the variations in the rate would ensure that a slightly differing amount actually arrived at each occasion. It would also explain why it didn't arrive on exactly the same day each week. Although it only took less than a second to make a computerised international transfer of money, the banks liked to make as much fuss as they possibly could about it so that the funds would swill around profitably in their system for a while.

But which country were the payments coming from? (...) Using the figures from the papers, he was able to construct a map of movements of each of the world's major currencies over the last few weeks and see how they compared with the fluctuations in the amounts that had been paid into his account every week. The answer sprang into focus immediately. US dollars.(...) (219-220)

And the solution is appropriately creative:

A few phone calls to the bank had established that tracing the money back to its origins was going to be hideously difficult, partly because it was an inherently complicated business anyway, partly because it quickly became clear that whoever had been paying the money to him had taken some trouble to cover his or her tracks (...) he was being paid by someone. Presumably that someone was paying him to do something, but what he omitted to say. Well, that was a client's privilege. But Dirk felt that he should respond to this generous urge to pay him, that he should do something. But what? Well, he was a private detective, and what private detectives did when they were being paid was mostly to follow people (The Salmon of Doubt, 2002: 224-225). 
As The Salmon of Doubt appeared posthumously, we will never know whether Gently delivered what was expected of him, but we can hope that he delivered something.

The situation was different in a large corporation, which happened to change owners while Ford Prefect was doing his usual fieldwork.

\section{The Hitchhikers Guide to the Galaxy as a Corporation}

The familiar $\mathrm{H}$-shaped building of the $\mathrm{HG}$ offices rose above the outskirts of the city, and Ford Prefect, on arriving at it, had broken into it in the familiar way. He always entered via the ventilation system rather than the main lobby because the main lobby was patrolled by robots whose job it was to quiz incoming employees about their expense accounts. Ford Prefect's expense accounts were notoriously complex and difficult affairs and he found, on the whole, that the lobby robots were ill-equipped to understand the arguments he wished to put forward in relation to them, and he preferred, therefore, to make his entrance by another route.

This meant setting off nearly every alarm in the building, but not the one in the accounts department, which was the way that Ford preferred it. (...)

"Mr. Zil-Doggo is no longer with this organization. " (...)

"Organization?" yelled Ford. "Organization? What a bloody stupid word for a setup like this!"

"Precisely our sentiments. Understructured, overresourced, undermanaged, overinebriated. (...) Time to get business on its feet, Prefect, (...) We at InfiniDim Enterprises (...) have bought out the Guide. (...) The Galaxy is changing, ... We've got to change with it. Go with the market. The market is moving up. New aspirations. New technology." (Mostly Harmless, 1992: 674).

It is 1992, but all the main elements of managerialese are already in place. Also, Ford Prefect notices, before Brunsson and Sahlin-Andersson (2000) did, that all kinds of companies and administrations were being turned into "organizations". Similarly, the security obsession was already well developed:

...Ident-I-Eeze. This encoded every single piece of information about you, your body and your life into one all-purpose-machinereadable card that you could then carry around in your wallet, and it therefore represented technology's greatest triumph to day over both itself and plain common sense. (...) (677)

The identity card permits Ford to enter the accountants' universe, and it impresses him, the intergalactic traveler, deeply, just as the Polish auditor said it should:

Ford hurried over to the terminal, sat in front of it and quickly dipped himself into its universe. It wasn't the normal universe he knew. It was a universe of densely enfolded worlds, of wild topographies, towering mountain peaks, heart-stopping ravines, of moons shattering off into seahorses, hurtful blurting crevices, silently heaving oceans and bottomless hurtling hooping funds.

So this was where accountants spent their time. There was clearly more to them than met the eye. He looked around carefully, trying not to let it all swell and swim and overwhelm him. (...)

Before long, insofar as such terms had any meaning in this virtual universe, a ledge loomed up ahead of him on which he could grip and onto which he could clamber. (...) $\mathrm{He}$ was in a four-dimensional topological model of the Guide's financial systems, and somebody or something would very shortly want to know why. (...) Swooping through virtual space toward him came a small flock of mean and steely-eyed creatures with pointy little heads, pencil moustaches and querulous demands as to who he was, what he was doing there, what his authorization was, what the authorization of his authorizing agent was, what his inside leg measure- 
ment was and so on. (...) Ford, holding his breath and praying very slightly, pulled Vann Harl's Ident-I-Eeze (...) (687-688).

If it sounds like science-fiction, it is because it is science-fiction. On the other hand, the pictures of Göteborg's municipal data base presented by Ann-Christine Frandsen in her dissertation Space, Time and Money: A Study of Accounting in Practice (2003), do not differ appreciably. Servers hidden between the iron bars, enormous data bases only the stereotype of accountants as "mean and steely-eyed creatures with pointy little heads, pencil moustaches and querulous demands" remains as it was.

Like Dirk Gently, Ford Prefect is also highly ethical in his doings:

About thirty minutes to do the job, and three minutes thirty to cover his tracks. (...) He could have transferred the ownership of the entire organization into his own name, but he ... didn't want it anyway. It would have meant responsibility, working late nights at the office, not to mention massive and time-consuming fraud investigations and a fair amount of time in jail. (Mostly Harmless, 1992: 689)

And this long before the Enron scandals. Ford Prefect seems to be describing the job of the owner as identical to the job of the Chief Accountess, as portrayed by the Polish incumbents. They claimed that it is neither the owner nor the General Manager, but they who might end up in jail...

Adams has certainly diagnosed the coming problems connected to contemporary accounting: identification difficulties and the new type of computerized crime. But what kind of future would Adams predict for accounting: will computerization lead to virtualization? Or has accounting always been virtual?

\section{Accounting, gender, and "feminine jobs"}

... we live in a world where the highest function of the sign is to make reality disappear and, at the same time, to mask this disappearance (Jean Baudrillard, 2002:5).
This provocative statement seems to be a good way to describe the practice of accounting in the contemporary global economy. What role will women have in this process?

The fact that accounting is perceived in Poland to be a "feminine" job does deviate from job stereotypes in other western countries, but it does not deviate from a pattern, which shows that "feminine" jobs are less prestigious and more poorly paid. I attempted to explain why and how accounting had become a feminine job in Poland, but a more general question remains unanswered. Are the feminine jobs less prestigious because they are more poorly paid or because they are "feminine"? Or, the other way around: are the feminine jobs more poorly paid because they are less prestigious, or because they are "feminine" (women do not bargain)?

I am certainly not the first person to pose such questions. Cheryl Lehman (1994) stated that "a sexual division of rigid, constraining, and low status roles in certain social positions for women, that has persisted for centuries in western society, requires conceptualization" (p. 262). On the way there, she rejected some possibilities:

That women's status in ranked societies is variable leads us to reject a conspiracy-type theory and the inevitability of a particular division of labor, but the underlying question of what caused, affected or stimulated the division and subsequent ranking (..) remains unanswered (pp. 262-263)

I could not agree more, but I am not sure I accept certain premises in this statement. To begin with, the variability of "feminine occupations" is certainly an argument for the social construction of both femininity and occupation. However, I would be pleased with a conspiracy theory, as conspiracies can be unmasked and destroyed. I suspect worse.

Looking for answers, Lehman reviewed the standard explanations of inequality known under labels of liberal feminism, socialist feminism, and radical feminism. As is often the case, it is difficult to understand why all these explanations cannot be correct at the same time, as intersectionality theory (Crenshaw, 1989) suggests. Let me then try my own explanation. 
Western societies (to keep to the minimal qualifier) share a contempt for women (Lehman, 1994: 265 , references US research on children, showing boys and girls demonstrating a fundamental distain for females). This contempt is reflected in the fact that whenever job or occupation is - for whatever reason - constructed as feminine, it loses status, as happened to clerks in western countries (Kirkham, 1994); to physiotherapists in Sweden (see Ottosson, 2005); and flight stewards in many countries (Mills, 2006). With the entrance of Anglo-Saxon models of management into Poland, the accounting profession will be divided into finance - jobs given to men - and accounting, in the sense of bookkeeping, which might remain "feminine" for one or two generations. Indeed, Thane (1994) seems to suggest that something similar happened to accounting in Britain during the early industrialization era and to personnel managers in the 1960s. In turn, when the barriers for women's entry into accounting in Anglo-Saxon countries are removed, the occupation will lose its status and remuneration. The only way out of this trap is a dramatically different socialization of children who, as Davies (1989) has convincingly shown, are fully socialized into traditional gender divisions at an early age. It is the contempt for women - shared by men and women alike - that must be eradicated. Accounting will adjust accordingly.

\section{References}

Adams, Douglas (1987). Dirk Gently's holistic detective agency. London: William Heinemann.

Adams, Douglas (1988). The long dark tea-time of the soul. London: William Heinemann.

Adams, Douglas (1996). The ultimate hitchhikers guide (five complete novels plus bonus story). New York: Random House.

Adams, Douglas (2002). The salmon of doubt. New York: Macmillan.

Balcerzak-Paradowska, Bożena (2004) Rozwia,zania prawnoinstytucjonalne $\mathrm{w}$ zakresie polityki społecznej - stymulator czy bariera zatrudnienia kobiet? Polska. Płeć a możliwości ekonomiczne w Polsce: czy kobiety straciły na transformacji? World Bank Document, 15 marca 2004, Raport Nr 29205. pp. 19-46.

Baudrillard, Jean (1995/2002). The perfect crime. London: Verso.
Beard, Victoria (1994). Popular culture and professional identity: accountants in the movies. Accounting, Organizations and Society, 19(3), 303-318.

Beksiak, Janusz (1994). O restauracji kapitalizmu w Polsce. In: 5 lat po czerwcu. Warszawa: Centrum Adama Smitha, pp. $11-32$.

Bougen, Philip D. (1994). Joking apart: the serious side to the accountant stereotype. Accounting, Organizations and Society, 19(3), 319-335.

Brown, Richard H. (1989). Social science as civic discourse. Essays on the invention, legitimation, and uses of social theory. Chicago, IL: The University of Chicago Press.

Brunsson, Nils, \& Sahlin-Andersson, Kerstin (2000). Constructing organizations: The example of public sector reform. Organization Studies, 21(4), 721-746.

Bystydzienski, Jill M. (1989). Women and socialism: a comparative study of women in Poland and the USRR. Signs: Journal of Women in Culture and Society, 14(3), 668684.

Calás, Marta, \& Smircich, Linda (1993). Dangerous liaisons: the "feminine-in-management" meets "globalization". Business Horizons(3-4), 73-83.

Chandler, Alfred D. (1962). Strategy and structure. Chapters in the history of the American industrial enterprise. Cambridge, MA: MIT Press.

Chandler, Alfred D. (1977). The visible hand: The managerial revolution in American business. Cambridge, MA: Belknap Press.

Crenshaw, Kimberle (1989). Demarginalizing the intersection of race and sex: A Black feminist critique of antidiscrimination doctrine, feminist theory and antiracist politics. University of Chicago Legal Forum, 139-167.

Czarniawska-Joerges, Barbara (1991). Culture is the medium of life. In P. J. Frost, L. F. Moore, M. R. Louis, C. C. Lundberg, \& J. Martin (Eds.), Reframing organizational culture (pp. 285-297). Newbury Park, CA: SAGE.

Czarniawska-Joerges, Barbara (1994a). Don Quixote and capitalism in Poland. In B. Czarniawska-Joerges \& P. Guillet de Monthoux (Eds.). Good novels, better management: Reading organizational realities in fiction (pp. 37-64). Reading, UK: Harwood.

Czarniawska-Joerges, Barbara (1994b). Gender, power and organizations. In John Hassard \& Martin Parker (Eds.), Towards a new theory of organizations (pp. 227-247). London: Routledge.

Czarniawska, Barbara (1999). Writing management. Organization theory as a literary genre. Oxford: Oxford University Press.

Czarniawska, Barbara (2000). A city reframed. Managing Warsaw in the 1990s. Reading, UK: Harwood Academic Publishers.

Czarniawska, Barbara (2002). A tale of three cities. Oxford: Oxford University Press.

Czarniawska, Barbara (2004). Women in financial services: fiction and more fiction. In Karin Knorr Cetina \& Alex Preda (Eds.), The sociology of financial markets (pp. 121-137). Oxford: Oxford University Press. 
Czarniawska, Barbara (2006). Doing gender unto the other: fiction as a mode of studying gender discrimination in organizations. Gender, Work and Organization, 13(3), 234-252.

Czarniawska, Barbara, \& Rhodes, Carl (2006). Strong plots. Popular culture in management practice and theory. In Pasquale Gagliardi \& Barbara Czarniawska (Eds.), Management education and humanities. London: Edward Elgar.

Davies, Bronwyn (1989). Frogs and snails and feminist tales, Allen; Unwin, North Sydney, AU.

DeCoster, Don T., \& Rhode, John Grant (1971). The accountant's stereotype: real or imagined, deserved or unwarranted. The Accounting Review, XLVI(4), 651-664.

De Vault, Marjorie L. (1990). Novel readings: the social organization of interpretation. American Journal of Sociology, 95(4), 887-921.

Evans, Lisa (forthcoming) Brothels, tombstones and morality. A literary look at offbeat perspectives on accounting and finance.

Gella, Alexander (1976). An introduction to the sociology of the intelligentsia. In Aleksander Gella (Ed.), The intelligentsia and the intellectuals. Theory, method and case study (pp. 9-34). London: Sage.

Guillet de Monthoux, Pierre, \& Czarniawska-Joerges, Barbara (1994). Management beyond case and cliché. In B. Czarniawska-Joerges \& P. Guillet de Monthoux (Eds.). Good novels, better management: reading organizational realities in fiction (pp. 1-16). Reading, UK: Harwood.

Hantrais, Linda (1995). A comparative perspective on gender and accountancy. The European Accounting Review, 4(2), 197-215.

Holmgren, Beth (1998). Rewriting capitalism: literature and the market in late tsarist Russia and the Kingdom of Poland. Pittsburg: University of Pittsburgh Press.

Johnson, Richard (1986-1987). What is cultural studies anyway? Social Text, 16, 38-80.

Józefowski, Wiesław (2004) Miłość w sanatorium. Wrocław: Astrum.

Kirkham, Linda (1994). Integrating herstory and history in accounting. Accounting, Organizations and Society, 17(3/4), 287-297.

Kirkham, Linda, \& Loft, Anne (1993). Gender and the construction of the professional accountant. Accounting, Organizations and Society, 18(6), 507-558.

Lehman, Cheryl R. (1994). "Herstory" in accounting: the first eighty years. Accounting, Organizations and Society, 17(3/4), 261-285.

Lisowska, Ewa (2004). Przedsie, biorczość kobiet w Polsce. Polska. Płeć a możliwości ekonomiczne w Polsce: czy kobiety straciły na transformacji? World Bank Document, 15 marca 2004, Raport Nr 29205, pp. 47-69.

Magnusdøttir, Audur (1999). Den starka kvinnan? Forskning and Framsteg, 5, 35-37.

Maltby, Josephine (1997). Accounting and the soul of the middle class: Gustav Freytag's Soll und Haben. Accounting, Organizations and Society, 22(1), 69-87.

Marrese, Michelle Lamarche (2002). A woman's kingdom. Noblewomen and the control of property in Russia, 17001861. Ithaca: Cornell University Press.

McCloskey, Deirdre N. (2006). The bourgeois virtues. Ethics for an age of commerce. Chicago: The University of Chicago Press.

Mills, Albert J. (2006). Sex, strategy and the stratosphere. London: Palgrave Macmillan.

Ottosson, Anders. (2005). Sjukgymnasten - vart tog han vägen? (The physiotherapist - what happened to him?) Gothenburg: Göteborg University, Dept. of History.

Parlińska, Maria and Sawicka, Janina (2004) Społecznoekonomiczna sytuacja kobiet wiejskich w Polsce. Polska. Płeć a możliwości ekonomiczne w Polsce: czy kobiety straciły na transformacji? World Bank Document, 15 marca 2004, Raport Nr 29205, 110-127.

Prus, Bolesław (1890/1987) Lalka. Warszawa: PIW. English edition: The Doll (1996) London: Central European University Press Book.

Rhodes, Carl, \& Brown, Andrew D. (2005). Writing responsibly: Narrative fiction and organization studies. Organization, 12(4), 467-491.

Sokołowska, Magdalena (1981). Women in decision-making elites: The case of Poland. In Cynthia Fuchs Epstein \& Rose Laub Coser (Eds.), Access to power: Cross-national studies of women and elites (pp. 90-114). London: Allen \& Unwin.

Sombart, Werner (1922/1967). Luxury and capitalism. Ann Arbor, MI: University of Michigan Press.

Szymborska, Wiesława (1993/1995). Nothing's a gift. In View with a grain of sand (pp. 206-207). New York: Harcourt Brace.

Thane, Pat (1994). The history of gender division of labour in Britain: reflections on 'Herstory' in accounting: the first eighty years. Accounting, Organizations and Society, 17(3/4), 299-312.

Walker, Stephen P. (2002). Men of small standing? Locating accountants in English society during the mid-nineteenth century. European Accounting Review, 11(2), 377-399.

Watts, Cedric (1990). Literature and money: Financial myth and literary myth. London: Harvester Wheatsheaf. 